\title{
Aspects of risk assessment in land use planning: the case study of Tartu
}

\author{
A. Tammepuu ${ }^{1}$, K. Sepp ${ }^{1} \&$ E. Uiga ${ }^{2}$ \\ ${ }^{1}$ Estonian University of Life Sciences, Estonia \\ ${ }^{2}$ Risk Management OÜ, Estonia
}

\begin{abstract}
The purpose of this work was to analyse the problems connected with the risk assessment of emergency situations in Estonia and their relations with land use planning. The research was carried out on the basis of a case study: the preliminary risk assessment of Tartu, the second largest city of Estonia, conducted by the specialists of the Estonian University of Life Sciences.

The Estonian Emergency Preparedness Act designates risk assessment as an important task of crisis management, on the basis of which all of the following measures should be planned and implemented. The act specifies two types of risk assessment, functional and territorial. The first involves the ministries and their areas of government, whereas the second concerns the counties and the largest cities and communities. The methodical basis of territorial risk assessment is established by special regulation of the Minister of the Interior. The regulation requires the determination and risk assessment of 15 (or more) different types of possible emergency situations. The outcomes of the risk assessments will serve as the basis for composing crisis management plans and spatial (land use) planning, concerning county plans, comprehensive plans, detailed plans, and also specific building projects.

At present, the risk assessments of all of the counties and most of the largest cities in Estonia have been performed, but the possibilities for the application of the outcomes for spatial planning remain uncertain. Our intention was to select and group the scenarios of development of emergency situation in relation with land use and spatial planning, and to draw up proposals for specific planning activities. On the basis of their relations to city area, the 15 types of possible emergency hazards were divided into five groups, which were described and analysed separately. The conclusions concerned the opportunities for taking into consideration the results of risk assessment in planning and design procedures. Keywords: risk assessment, land use planning, public safety.
\end{abstract}




\section{Introduction}

The whole existence of mankind and its activities are entirely concerned with the use of land. All human activities, as well as all natural conditions pose hazards for human beings and/or the environment, and therefore involve certain elements of risk [1]. The consequences of unwanted events are spatially distributed, depending on multiple hazard and safety factors: the character of the risk source, the pathways of hazard factors, the vulnerability of specific objects and systems, protective barriers etc. Population growth has made land scarcer, especially in urban areas, which leads to ever more intensive use of available space [2] and an increasing likelihood of adverse interactions and impacts.

Today a wide range of professions and academic subjects use the technique of risk assessment [3]. Risk assessment is an essential component of the overall management of risks within society, and specifically risks to human health and/or the environment [4]. It is the first step in explaining the problems and evaluating the significance of risk either quantitatively or qualitatively [5]. Although today's society is greatly concerned with many aspects of risk, the concept of risk and its assessment and management have not yet been sufficiently developed to meet many challenges [6]. Risk assessment is an essential part of civil protection. In many European countries the usefulness of the further development of risk assessment in the field of civil protection and emergency preparedness is clearly recognized [7].

An important landmark in the development of risk assessment and land use planning (LUP) in the context of major hazards involving dangerous substances is Council Directive 96/82/EC of 9 December 1996 on the control of majoraccident hazards involving dangerous substances (the "SEVESO II" Directive) $[8,9]$. The consequences of major industrial accidents can cause remarkable damage in surrounding areas. Article 12 of the Seveso II-Directive requires that the objectives of preventing major accidents and limiting their consequences be taken into account by the Member States in their land use policies and/or other relevant policies [8-10]. Risk assessments are increasingly used in land use planning with the purpose of minimizing the undesirable effects of accidents at hazardous installations. An emerging and important aspect of risk-based land use planning concerns the aspect of integrated risk assessment and management. [11]. For the siting of new establishments, the hazards of accidents and the environmental impact from continuous emissions could be considered together in order to have an integrated assessment of the environmental compatibility of the proposed activity [12].

At present, after the recent enlargement of the European Community, only a limited number of European countries have developed specific criteria for LUP with respect to major accident hazards [13]. From the methodological point of view, two approaches adopted in support to land use planning decisions can be distinguished in the countries of the European Union: the first, called a "consequence-based" approach, focuses on the assessment of the consequences of a number of conceivable event scenarios, and the second, called a "risk based" approach, focuses on the assessment of both the consequences and probabilities 
of possible event scenarios occurring $[9,14]$. A third methodological approach that could also be considered consists of the determination and use of "generic" distances that depend on the type of activity rather than on a detailed analysis of the specific site $[9,14]$.

Although the term land use planning is mostly discussed in the context of major hazards in fixed installations, these are not the only hazards for which LUP is necessary [12]. For example, the risks arising from the transportation of dangerous chemicals are often of the same magnitude as those that are due to fixed installations, and thus need to be taken into account with the same attention in order to keep them under control and to reduce them [15]. Smith discusses the problems of the land use planning of several environmental hazards on the basis of the experiences of different countries [5].

The goals of this study were first to give an analytical description of risk assessment in the field of emergency preparedness in Estonia as a whole and in the city of Tartu. Second, to develop further the methodology of using risk assessment results for land use and spatial planning in the case study of Tartu.

\section{Emergency risk assessment and spatial planning in Estonia}

\subsection{Risk assessment}

In Estonian legislation, risk assessment is defined as the systematic determination and evaluation of possible accidents and risk sources and the planning of measures for their prevention [16]. The requirements for risk assessment in the field of emergency preparedness and crisis regulation are enacted in the Emergency Preparedness Act [17]. Risk assessment in the field of civil protection in Estonia took its first steps in the middle of the last decade. One important development was the translation of the UNEP/APELL guidebook: Hazard Identification and Evaluation in a Local Community [18] into Estonian in cooperation with the Estonian Rescue Board and Swedish Rescue Board. Several courses and information seminars were held [19], and thus specialists from all over the country were able to receive elementary knowledge in the field of contemporary risk assessment. Since the middle of the 90s, basic courses of risk assessment were taught at Estonian universities.

As in Finland, Sweden and Norway [7], a nation-wide system of risk assessment is also applied in Estonia. The Estonian Emergency Preparedness Act establishes risk assessment as an important task of crisis management, on the basis of which all the following measures should be planned and implemented [17]. The act specifies two types of risk assessment: functional and territorial. The first involves the ministries and their areas of government, whereas the second concerns the counties and the largest cities and communities. Both types of risk assessments use methods of preliminary assessment. The result of such preliminary assessment is the ascertainment of hazards that have the potential to develop into emergencies, and the general description of the probabilities and consequences of these hazards. 
The methodological basis for ministries' risk assessment (the functional approach) is the guidance document "The Schedule and Methodology of Ministerial Risk Assessment" [20] conformed with the decision of the Crisis Commission of the Government of the Republic of Estonia. The goal of the risk assessment of ministries is to ascertain possible emergencies in the fields of government of ministries. An important task of the risk assessment of ministries is risk assessment in the institutions in the field of government of ministries. In determining emergency situations, institutions shall proceed from the duties enacted in their charter, which means determining the emergencies in its fields of government and assessing hazards. These risk assessments are event-based, i.e. the probabilities and consequences of events and the hazards causing them are analysed. It is not necessary to go into detail. Risks classified as high ones, could later be analysed in greater detail.

The methodological basis for territorial risk assessment is established by special regulation of the Minister of the Interior [16]. The goal of risk assessment in the context of the regulation is to determine and assess certain types of possible accidents in the territory of counties, communities or cities and the probabilities of their occurrence, thereby obtaining an overview of the potential hazards for state security, human life and health, environment and critical infrastructures. Factually, the methodology requires preliminary assessment of multi-hazard risks, the primary types of which are prescribed. The outcomes of risk assessments are established as the basis for composing crisis management plans and spatial (land use) planning, concerning county plans, comprehensive plans, detailed plans and also specific building projects. This is an important fact, which expresses the need for the further development of a more effective linkage between risk assessment and land use planning.

The risk assessments of hazardous installations are important source data for territorial risk assessment. The Chemicals Act establishes the requirements for chemically hazardous enterprises [21], in which hazardous installations are determined and divided into three categories. The thresholds of the two more strict categories are these of the Seveso II Directive, and these are plants with major accident hazards. For the third category, so-called (simply) 'hazardous enterprises', the threshold quantities are remarkably lower than prescribed in the Seveso criteria. For example, the threshold quantity for gasoline is 10 tonnes, and thus most petrol stations belong to that group. These hazardous installations are also obliged to carry out risk assessments and prepare emergency plans.

At present the risk assessments of all of the ministries (except for the Ministry of Defence, which is not required to do so), counties and most of the largest cities in Estonia have been performed. The Ministry of the Interior has composed a summary of risk assessments of ministries and counties [22]. The aim of the summary was to offer a brief introduction to the principles of risk assessment applied in the system of emergency preparedness and crisis regulation. The summary points out the ten types of risk that have been assessed as the highest, and makes recommendations for the management of these risks. 


\subsection{Spatial planning}

The purpose of planning in Estonia is to ensure conditions that take into account the needs and interests of the widest possible range of members of society for balanced and sustainable spatial development, spatial planning, land use and building [23]. Spatial planning is democratic and functional long-term planning for spatial development that co-ordinates and integrates the development plans of various fields and in a balanced manner takes into account the long-term directions in and needs for the development of the economic, social, cultural and natural environment.

The Planning Act defines four levels of planning - national, county, comprehensive and detailed. The latter two are relevant in the urban context. A comprehensive plan is prepared for the whole territory of a rural municipality or city or parts thereof.

The comprehensive plan defines the main directions and conditions for the development of the territory of a town or community, to prepare the basis for composing the detailed plan for areas and cases where detailed planning is mandatory, and to prepare the basis for adjusting the land use and building criteria for areas where detailed planning is not mandatory. Several tasks of comprehensive plans should also consider aspects of environmental risk: to establish conditions for sustainable and balanced spatial development; determine general use and building provisions for land and water areas; define the location of roads, streets, railways, ports and airports and the general principles of traffic management; define the location of principal utility network routes and technical infrastructure, take account of general national defence needs and, where necessary, to designate national defence areas and specify the boundaries of national defence areas designated by the county plan and address in the plan land use provisions and building provisions arising from Acts and other legislation.

A detailed plan is prepared for a part of the territory of a rural municipality or city, and it serves as the basis for building activities and land use in the short term. The purpose is to guide the land use and construction criteria in towns and small towns and in other areas and cases where detailed planning is mandatory [24].

\section{Materials and methods}

The methodological basis of risk assessment in the city of Tartu was the document "Methodology of Risk Assessment of County, City and Community", enacted by regulation of the Minister of the Interior [16]. The risk assessment can be characterised as semi-quantitative: a risk matrix approach which uses a 5step ranking for the assessment of probability (1-5, where 1 was the lowest and 5 the highest) and the consequences (A-E, where $\mathrm{A}$ was the least serious and $\mathrm{E}$ the most serious) united into the matrix, based on the principles analogical to the APELL/UNEP methodology [18].

The initial information was collected in cooperation with Tartu City Government. The risk sources in the town were identified through the 
classification of the methodology: local risk sources, moving risk sources, risk sources without definite location (for example extreme environmental conditions) and risk sources that threaten public safety (disturbance of the supply of some essential resource). The following analysis and assessment of risks was conducted on the basis of corresponding accident types:

1) fires

2) explosions

3) transport accidents

4) accidents with dangerous chemicals

5) drinking water pollution

6) accidents on water bodies

7) accidents involving communal systems

8) breakdowns of electricity supply

9) breakdowns of communication systems

10) gas accidents

11) floods

12) collapses (buildings)

13) extreme environmental conditions

14) epidemics

15) epizootics.

The probabilities of the accidents occurring were assessed indirectly, taking into account the existing statistics of accidental events and also the possible internal and external reasons and initial events that could activate accident scenarios. The consequences of each selected accident scenario were first assessed separately using the following four tasks: human life and health, essential sectors, environment and property, each task in a five-point ranking and after that, secondly, a general appraisal was given. The risks were collated by magnitude, and the proposals for mitigation measures were developed.

This embraced our attempt to find and describe characteristic features by which the accident types and concrete emergency scenarios could be distinguished and analytically described as concerns their relation to the rural and urban environment, and to group these events on the basis of the characteristic features for further practical application.

\section{Tartu case study}

\subsection{Risk assessment in Tartu}

Tartu is Estonia's second largest city, with 98,313 inhabitants [25]. The area of the city is $38.8 \mathrm{~km}^{2}$, which means that the city's territory is quite densely inhabited. The average population density is ca 2600 inhabitants per square kilometre.

The City Government of Tartu has ordered several studies of environmental risk. In 2002, for example, the Tallinn University of Technology carried out a risk assessment in Tartu [26] which mostly focused on critical infrastructures. In 2003 Tammepuu, who compiled an expert opinion about the study, stated that 
the work profoundly treated the selected tasks in depth but only partially corresponded to the established requirements [27]. In 2004 the working group on spatial planning of the Department of Human Geography of the University of Tartu carried out a study concerning the linkage between risk assessment and urban space [28], based on the results of the risk assessment of Tallinn University of Technology. The authors recognized that present-day city planning did not consider hazard zones, and these aspects need to receive more attention in future. In 2005 the workgroup of the Department of Human Geography performed a study on flood risks in Tartu [29]. In addition to the abovementioned studies, the risk assessments of hazardous enterprises were performed by several persons, using different methodical approaches. Thus the previous risk assessments could be divided into two groups: risk assessments and expert opinions ordered by the city government and risk assessments of hazardous installations.

The preliminary risk assessment of Tartu in 2005 was carried out by specialists of the Estonian University of Life Sciences [30]. The general conclusion of the study was that in Tartu the occurrence of emergencies of different types was of low or moderate probability. The preliminary risk assessment showed clearly that the situations considered to be probable causes of emergencies were the following: accidents with ammonia, LPG and fuel containers and carriages, the pollution of water supply and long-lasting interruptions of water, electricity and gas supply, comprehensive disturbances in communication systems and extreme meteorological conditions.

The assessed probability of serious accidents was estimated to be higher in the parts of the town that contained a greater number of hazardous enterprises, and through which the railway passes. An accident with a railway carriage containing ammonia was expected to be the worst case of a chemical accident. Several important and vulnerable objects remain in the hazard zone, including Tartu University Hospital. In addition to the railway transport of ammonia only one enterprise, which uses ammonia in refrigeration technology, has remained in place of about ten in the last decade, which means that in this sense the situation has improved remarkably.

Liquid fuels transported both by railway and by road are also an important component in the context of considerable accidents with chemicals. The most serious fires were expected in the occasion of accidents with flammable chemicals. Possible accidents with truck carriages of petrol were assessed as being most problematic in filling stations, especially for those stations situated in densely inhabited areas. The accident with the fuel truck was supposed to be the most serious situation in petrol stations which formed the majority of the hazardous installations in Tartu. The possibility of explosion was also evaluated as being the highest in the case of an accident with chemicals.

In addition to chemically hazardous plants and the transport of dangerous goods, serious fires are possible in enterprises that store large quantities of flammable materials. This primarily concerns the timber industries. Another type of object where fires were estimated to have serious results were buildings where the presence of large number of people was expected (department stores, 
theatres, concert and sports halls etc.). There are also relatively large areas on the city's territory where wildfires can take place, and districts in which old timber houses are situated problematically close to each other, increasing the hazard of extensive fires involving a group of buildings.

Critical infrastructures play an important role in the rise of the emergencies from one side and in mitigation and reacting activities from the other. The insufficiency of water supply was observed to be the most serious type of accident in communal systems and networks, the most expected reason for which was the long-term interruption of electricity supply. The hazard of drinking water pollution was assessed to be highest at one of the water intakes, which covers about $40 \%$ of the water supply of Tartu and therefore can independently cause an emergency. Extensive and long-lasting interruptions of electricity supply are possible due to both external causes (not dependent on installations in city areas) and internal causes. Tartu is vulnerable because of the lack of reserve electricity generators, a limited number of which can be found at some important objects. Large-scale disturbances in the work of communications systems can firstly independently cause emergencies or secondly have an impact on various kinds of emergencies.

The influenza and other similar viral infections were considered to be the most probable causes for the outbreak of large-scale epidemics.

\subsection{Results of complementary analysis}

The goal of the study was to select, group and analyse the scenarios of the rise of emergency situations in relation with land use and spatial planning in Tartu and to develop measures to mitigate environmental risk. The 15 types of possible emergency hazards were divided into 5 groups that were described and analysed separately.

The first group comprises events that are characterised by the existence of a specific and localised risk source. Accidents at hazardous installations could be the typical example of that group. There are no enterprises with a major accident hazard corresponding to the Seveso II criteria in Tartu, but there are 27 objects that the Estonian Chemicals Act treats as hazardous installations; most of these are petrol stations. These events can be characterised by definite hazard (or safety) distances and/or zones, on the basis of certain criteria. In addition, industrial plants using large quantities of flammable materials (not chemicals), for example timber, could be classified into this group.

The second group involves events with moving sources of risk and logistics chains. This primarily involves possible accidents on railways and roads/streets but also water traffic on the Suur-Emajõgi River and also to a certain extent accidents on gas pipelines and high-voltage electricity lines, as the latter can be characterised as the carriers of (moving) substance or energy, uncontrollable emissions of which could cause adverse outcomes. In the case of the transportation of dangerous chemicals, the hazard zone is principally ribbonshaped, in the centre of which is the observed route or in other words: the hazard (or safety) zone, which is circular for a localised object, moves together with the 
risk source. It is important to mention that the probabilities of accidents occurring are not the same in all places on the routes, and also influenced by traffic density, which is time-dependent.

These two groups can be treated similarly in relation to possible chemical accidents. The methods used for risk assessments in the hazardous installations of Tartu for the identification of safety distances were mostly "generic" and/or "consequence-based" (drawing an analogy with the Seveso II terms). Various criteria were used by different experts for the determination of safety distances (or identifying hazard or safety zones) during the performance of risk assessments of concrete hazardous objects. The data from norms, standards, handbooks and practical experiences has been applied in these assessments for the determining of "generic" distances. The "consequence-based" approaches have used the criteria from different sources, including some of those applied for Seveso II enterprises in other European Union countries [31,32]. The main solutions for the near future could be the determination and harmonization of recognized (and preferably legalized) methodological approaches and criteria for modelling and assessing the consequences throughout Estonia. There could be a gradually shift towards the use of more detailed and quantitative methods. We suggest that the usage of "generic", "consequence-based" and perhaps "riskbased" approaches could initially exist simultaneously in Estonian practice. At the same time, this requires the preparation of a methodology for the comparison and /or combination of the results obtained by different approaches. Another important task for risk assessors, managers and planners, real estate developers etc. is the specification of the limitations of planning and building in hazard zones.

The third group contains events where the risk source does not have a specific localisation, but could be found on a limited area. These areas of distributed risk source can be marked on a map. Typical events of this group are, for example, wildfires and fires in districts with a high proportion of old timber houses, where the level of fire protection is low. The fire protection level should be increased via measures proposed in spatial planning and projecting (for example the selection of construction materials, the installation of centralised fire alarm systems, the reconstruction of the fire-fighting water supply, the observance of fire safety distances and the planning of protective barriers etc.). Floods were also classified in this group, as the limiting factor is the increase of the water level, and the accidentally flooded area is dependent on the height, which limits the areas of the flood with observable probability. These areas are mapped, and conditions for the land use are established through comprehensive or thematic planning.

The fourth group can be characterised by the keywords 'networks' and 'deficiency'. This means, that probable emergency situations with certain critical infrastructures can be characterised as events in which the main problem is not the surplus of matter or energy but the shortage thereof. This concerns electricity, water, gas supplies and communication systems. Thus the hazards depend on the normal functioning of the chain of supply from the reservoir or generator of the required resource to the intermediate distributors and final consumers. The initial 
event causing the absence or lack of the resource can take place in each part of the chain or network. In connection with such events, the mapping and planning of networks could be examined from the point of view of reliability and risk. Factors that should definitely be considered are: the technological state of the network elements and the presence and/or possibility of alternative supply. Spatial planning should consider the opportunities for modernizing the specific network sectors and the application of alternative sources and channels of feeding or supply.

The fifth group covers events that are 'hardly localizable', where the exact or even indirect identification of a hazard area during risk assessment and taking it into account in spatial planning procedures on the city level is almost impossible. This group contains such accidental events as natural disasters: thunder, snow and hailstorms, extreme snow conditions, unusually high and low temperatures etc. A technological emergency like a nuclear accident in a neighbouring country also falls into this category in the context of municipal risk assessment and planning. Although this kind of event has a certain localized risk source, the impact depends on meteorological conditions. These kinds of possible events do not enable one to map the specific risk or hazard or safety zones in the risk assessment of the city, but allow one to identify more vulnerable objects and take these into account in comprehensive planning, and certainly plan measures in the city's crisis management plan.

\section{Conclusions}

The preliminary risk assessment of the town of Tartu and the opportunities for applying risk assessment outcomes in spatial planning were studied in the context of multiple hazards and emergency scenarios. Whereas previous studies $[26,28,29]$ focused on a limited number of events and proposed specific solutions, we tried to explore the risk aspects more broadly, and certain characteristics of systematisation and grouping the accident types were identified in relation to land use and planning. On the basis of the selected criteria, the main accident types were grouped into 5 clusters that could be applied in mapping, planning and projecting/management procedures.

The study shows clearly that the experiences of other EU member states (which are in that sense more developed) could only partially be adopted. There are remarkable differences between the EU countries in the implementation of risk assessment and land use planning. We emphasize the urgent need for further improvement of risk assessment and crisis management in Tartu. One important task in this area is to consider the risk assessment outcomes in spatial planning, which helps to mitigate risk and increase environmental and public safety.

\section{References}

[1] Kirchsteiger, C., Trends in accidents, disasters and risk sources in Europe. Journal of Loss Prevention in the Process Industries, 12, pp. 7-17, 1999. 
[2] Suddle, S. \& Ale, B., The third spatial dimension risk approach for individual risk and group risk in multiple use of space. Journal of Hazardous Materials, A123, pp. 35-53, 2005.

[3] Fairman, R., Mead C.D. \& Williams P.W., Environmental Risk Assessment, Approaches, Experiences and Information Sources. King's College London for the EEA, Copenhagen, pp. 17-18.

[4] Report of the OECD Workshop on Risk Assessment and Risk Communication in the Context of Chemical Accident Prevention, Preparedness and Response. OECD Environmental Health and Safety Publications, Series on Chemical Accidents, No. 1. Paris, 1997.

[5] Smith, K., Environmental Hazards: assessing risk and reducing disaster. Routledge: London \& New York, 2001.

[6] Aven, T. \& Kristensen V., Perspectives on risk: review and discussion of the basis for establishing a unified and holistic approach. Reliability Engineering and System Safety, 90, 1-14, 2005.

[7] Report on risk assessment procedures used in the field of civil protection and rescue services in different European Union countries and in Norway. http://europa.eu.int/comm/environment/civil/pdfdocs/riskassfinrep.pdf

[8] Council directive 96/82/EC of 9 December 1996 on the control of majoraccident hazards involving dangerous substances, OJ No L 10 of 14 January 1997 (Seveso II-Directive), and Directive 2003/105/EC of the European Parliament and of the Council of 16 December 2003 amending Council directive 96/82/EC, OJ of 31 December 2003.

[9] Christou, M.D. \& Porter, S., (eds). Guidance on land use planning as required by Council Directive 98/82/EC (Seveso II). Joint Research Centre, European Commission, EUR 18695 EN, 1999.

[10] Hauptmanns, U., A risk-based approach to land-use planning. Journal of Hazardous Materials, A125, pp. 1-9, 2005.

[11] Magnusson, S.E., Göransson, P., Petersen, K., Malmen, Y., Hovden, J., Ringdahl, L.H. \& Akselsson, R., Nordic Industrial Fund, project P98087, Co-operative Nordic Risk Research Project report, 1999.

[12] Christou M.D., Amendola A. \& Smeder, M., The control of major accident hazards: the land use planning issue, Journal of Hazardous Materials, 65, pp. 151-178, 1999.

[13] Cozzani, V., Bandini, R., Basta, C. \& Christou, M.D., Application of land-use planning criteria for the control of major accident hazards: A case-study, Journal of Hazardous Materials, 136, pp. 170-180, 2006.

[14] Christou, M.D., Land use planning (Chapter 4). Risk Assessment and Management in the context of the Seveso II Directive, eds. C. Kirchsteiger, M.D. Christou \& G.A. Papadakis, Industrial Safety Series, Volume 6, Elsevier, pp. 437-469, 1998.

[15] Leonelli, P., Bonvicini, S. \& Spadoni, G., Hazardous materials transportation: a risk-analysis-based routing methodology, Journal of Hazardous Materials, 71, pp. 283-300, 2000. 
[16] Maakonna ning valla ja linna riskianalüüsi metoodika [Methodology of risk assessment of the county, the community and the city] Appendix to the State Gazette, 82, 1112, 2001.

[17] Emergency Preparedness Act. State Gazette I, 95, 613, 2000.

[18] Hazard Identification and Evaluation in a Local Community, UNEP IE/PAC, 1992.

[19] Põder, T. Keskkonnamõju ja keskkonnariski hindamine. Käsiraamat. [Environmental Impact and Risk Assessment. Handbook]. Tallinn, pp. 78, 2005.

[20] Ministeeriumi riskianalüüsi ajakava ja metoodika [The schedule and methodology of ministerial risk assessment], Ministry of Internal Affairs, 2005. http://www.sisemin.gov.ee/atp/failid/riskianalyysi_metoodika.pdf

[21] Chemicals Act. State Gazette I, 47, 697, 1998.

[22] Ministeeriumide ja maakondade riskianalüüsi kokkuvõte 2005 [Summary of the risk assessments of the ministries and the counties 2005], The Ministry of the Interior of Estonia, Internal Security Analysis Department, Bureau of Crisis Management: Tallinn, 2006. www.kul.ee/webeditor/files/riskianaluusi_kokkuvote_.pdf

[23] Planning Act. State Gazette I, 99, 579, 2002.

[24] Külvik, M., Sepp, K., Jagomägi, J. \& Mander, Ü., Ecological networks in Estonia - from classical roots to current applications. Multifunctional Landscapes, Volume III, Continuity and change, eds. Ü. Mander \& M. Antrop, WIT Press, 2003.

[25] Tartu http://www.tartu.ee/

[26] Tartu linna riskianalüüs [Risk assessment of Tartu City] Tallinn University of Technology: Tallinn, 2002.The Archives of the City Government of Tartu.

[27] Tammepuu, A., Eksperthinnang Tartu linna riskianalüüsi materjalidele. [Expert assessment to the materials of Tartu city risk assessment] Tartu, 2003. The Archives of the City Government of Tartu.

[28] Ahas, R., Silm, S., Aasa, A., Oja, T., Indus, K, Ojasoo, E., Rahu, K. \& Vaher, K., 2004. Tartu riskianalüüsi ruumiline sidumine ja analüüs. TÜ inimgeograafia õppetooli keskkonnaplaneerimise töörühm, [The spatial linkage and analysis of the risk assessment of Tartu. Work Group of Planning of the Department of Human Geography of the University of Tartu]. Tartu, 2004. The Archives of the City Government of Tartu.

[29] Ahas, R., Silm, S., Aasa, A., Karu, H., Luud, A. \& Sootla, I., Ilmastikutingimustest tulenevad tulvaveeriskid Tartus. TÜ inimgeograafia õppetooli keskkonnaplaneerimise töörühm [Flood risks from weather conditions in Tartu. Work Group of Planning the Department of Human Geography of the University of Tartu]. Tartu, 2004. The Archives of the City Government of Tartu.

[30] Tammepuu A. \& Uiga E., Tartu linna esialgne riskianalüüs, [Preliminary risk assessment of Tartu city] Estonian University of Life Sciences, Institute of Technology: Tartu, 2005. 
[31] Salvi, O. \& Gaston, D., Risk assessment and risk decision-making process related to hazardous installation in France, Journal of Risk Research, 7(6), pp. 599-608, 2004.

[32] Lauridsen, K., Kozine, I., Markert, F., Amendola, A., Christou, M. \& Fiori, M., Assessment of Uncertainties in Risk Analysis of Chemical Establishments. The ASSURANCE project. Final summary report. Risø National Laboratory, Roskilde, Denmark, 2002. http://www.risoe.dk/rispubl/SYS/syspdf/ris-r-1344.pdf 